\title{
SiM
}

\section{Sheep Production in the Mixed-Farming Systems of Mexico: Where Are the Women?}

\author{
By Veronica Vázquez-García
}

\section{On the Ground}

- Mexican scholarship has often obscured women's contributions to small-scale sheep production by using imprecise descriptions as to who producers are, what they do, and why. Such women can become invisible to researchers and policy makers.

- A gender-based approach is needed to raise the profile of these women. This could include clarifying how and why sheep-production duties are allocated between women and men in households and understanding how and why policies differentially affect women and men in terms of their access to productive resources and entitlement programs.

- Mexico needs to increase sheep productivity. Women are key stakeholders in this process. Production interventions could be facilitated by targeting women clients and making better use of their knowledge and practical experience.

Keywords: gendered roles in livestock management, rangelands, diffusion of innovations, small ruminants.

\section{La producción ovina en los sistemas agropecuarios mixtos de México:}

\section{¿dónde están las mujeres?}

\section{Perspectiva desde el campo:}

- La ciencia veterinaria mexicana ha invisibilizado la contribución femenina a la producción ovina de pequeña escala, al dejar de lado el análisis de quiénes son los productores, qué hacen y por qué.

- Se requiere un enfoque de género para visibilizar a estas mujeres. El uso de dicho enfoque ayudará a entender la asignación de labores entre hombres y mujeres así como el impacto diferenciado de la política pública en términos del acceso a recursos productivos y programas de apoyo.

- México necesita aumentar su producción ovina. Las mujeres son actoras clave en este proceso. Para aumentar el éxito de las intervenciones dirigidas a este objetivo, es necesario partir de los conocimientos y experiencias prácticas de las mujeres.

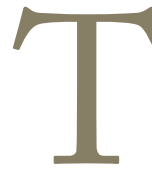
wo thirds of the world's poor, rural people live in mixed-farming systems that combine extensive or semi-intensive livestock production with agricultural crop cultivation. ${ }^{1}$ Animals provide meat, milk, fiber, power, and manure in these systems. In addition, livestock are a form of savings and insurance against accidents, illness, and death. As social assets, livestock contribute to building social capital because animals are often used as gifts or in cultural ceremonies (i.e., weddings, fiestas).
Women are clearly recognized for their vital roles in smallscale livestock production, and this is usually a very important dimension of mixed-farming systems. ${ }^{2}$ This does not mean, however, that women formally own the animals or benefit from animal sales. In general, women have less access and control over grazing land, water, fodder, credit, markets, and veterinary services when compared to men. Women's labor and responsibilities remain under-recognized and underappreciated in policy design and implementation. ${ }^{3}$ 
In this paper I examine the literature on women's roles in sheep management in the mixed-farming systems of Mexico. I have divided the paper into five sections. The first discusses the major characteristics of sheep production in the country. The second explores women's roles in sheep management, arguing that - despite their importance — these roles are rarely central in the analyses presented by most livestock scientists. In the third section I offer some conceptual tools to address this gap and better represent gender concerns. Finally, the last two sections summarize and discuss the main points of the paper as well as their major implications for the sheep industry of Mexico.

\section{Setting the Context: Sheep Production in Mexico}

Sheep, together with goats, cows, horses, pigs, chickens, and rabbits, were brought to Mexico during the Spanish invasion that started in $1492 .{ }^{4}$ By the nineteenth century Mexico exported mutton, lamb, and wool. The land distribution process resulting from the Mexican revolution of 1910 reduced flock sizes, but sheep have continued to be an important part of the rural economy. Currently, sheep are used to prepare barbacoa, a traditional dish that is particularly popular in central Mexico. Wool is used to manufacture traditional clothing and handicrafts. ${ }^{5}$

\section{National Sheep Inventory and Production}

In 2011 the Mexican government ${ }^{6}$ reported that the national flock size consisted of 8.2 million head of sheep. Half (49\%) were in five central states: State of Mexico (15.9\%), Hidalgo (13.4\%), Veracruz (8.1\%), Oaxaca (6.1\%), and Puebla (5.5\%). The national inventory grew by $14 \%$ between 2005 and 2011 .

Mutton and lamb account for about $1 \%$ of all meat consumed in Mexico. Per capita consumption of mutton and lamb is low compared to beef: $16.5 \mathrm{~kg} /$ person/year (beef) versus $1.0 \mathrm{~kg} /$ person/year (mutton and lamb) in $2001 .^{7}$ In 2011, mutton and lamb production met only half of the domestic demand, so frozen lamb and mutton were imported from the US, New Zealand, and Australia. Wool production in Mexico is in decline due to increasing use of synthetic fibers. In 1980, total production was 6,554 tons. ${ }^{8}$ By 2011, this amount had decreased by $29 \%$ to 4,696 tons. To meet domestic demand, wool must be imported from Argentina, China, and the US. ${ }^{9}$ The Mexican Association of Sheep Breeders considers sheep raising an area of opportunity that deserves investment incentives. With adequate government support, local producers should be able to meet domestic demand. ${ }^{10}$

\section{Three Livestock Systems}

Scholars have identified three systems to account for livestock production in Mexico: intensive, semi-intensive or mixed, and extensive. ${ }^{11-13}$ In the first, animals are confined and producers depend on high-performing breeds, industrial inputs, waste management, and food-safety measures. In mixed-farming systems, animal feeding is based on grazing native rangeland, roadsides, or crop residues, with limited use of supplements. Finally, in extensive production systems animals receive the fewest inputs and typically forage on rangelands.

The mixed-farming systems are the most important with respect to sheep production. The majority of production units in mixed-farming systems raise sheep for income and subsistence purposes. ${ }^{1-13}$ This is why I have decided to focus on women and sheep in mixed-farming systems.

\section{Women's Roles in Sheep Production: Three Dominant Views}

After a thorough literature review of Mexican scholarship involving some 30 papers, I identified three very different ways that scientists characterize women's roles in sheep production. Examples follow.

\section{The (Male) Sheep Producer}

The most common term to describe people who raise sheep is that of "producers" (gender is generally not provided). Although not clearly stated, producers are assumed to be male heads of households who are also the main breadwinners. As such, they are responsible for agricultural production, all income-generating activities, and sheep husbandry.

For example, Pérez-Hernández and collaborators ${ }^{12}$ state that one of the major disadvantages of subsistence sheep producers (read men) is that they have other jobs-bricklayers, drivers, construction workers, casual laborers-and do not have time to take proper care of sheep. In a similar vein, a study by Martínez-González and collaborators ${ }^{13}$ investigated producers' previous experiences with sheep husbandry, their likelihood of adopting innovations, and their access to production information. Even though the authors categorized producers by gender according to their methods, the paper does not provide any information on the sample's gender distribution, nor does it consider gender a variable when distinguishing attitudes towards innovation. Women are invisible.

\section{Family Labor}

Labor is a major aspect of sheep production. The more extensive or subsistence-oriented the farming system is, the more likely it will rely on family labor. There is less reliance on technology and a high dependence on people to herd and provide hands-on care for animals. To many scholars, such labor is never dissected out. Rather, it is broadly considered that this labor is conducted by "family members" or "women, children, and the elderly."

According to Arriaga-Jordán and collaborators, ${ }^{14}$ women, children, and the elderly take care of sheep because "many of them would not be able to find remunerated activities given their other responsibilities (e.g., domestic responsibilities of women), time devoted to the activity (e.g., school children who tend the animals before and after school), or due to old age." Their labor is a resource that "could not otherwise be utilized" (italics are mine). One is left wondering whether these groups of people really have more 
free time than anybody else (as opposed to greater burdens) and fewer employment options than others. Women's contributions to the rural economy have been well documented by feminist scholarship, belying the assumption of women's time availability or focus otherwise purely on nonremunerated activities. ${ }^{15}$

Moreover, the all-encompassing term "family labor" prevents scholars from examining differences in decision-making power within households. See, for example, the following quotes (italics are mine):

"Animals also represent a source of savings (in many instances the only one accessible to campesino families) which provide them with money in times of need, be it illness or disease, or to meet social commitments like weddings, end of school year and family parties, funerals, or religious festivities." 16

"Sheep are used to cover cash needs when needed, and if the family can afford it, they are sold to buy, or exchanged for, a bull calf to initiate the ploughing team."16

The family is conceived as a harmonious, homogeneous, and unitary body, with a decision capacity of its own, ignoring the fact that it is made up of specific individuals differentiated by gender, kinship, and age. It is the individuals, rather than abstract families, who are the ones that actually make decisions regarding livestock. Priorities are established by the more powerful people within the household and decisions may not necessarily benefit all members equally. This approach lacks any real understanding of the differences among household members in terms of labor demands, social status, and decision-making power.

\section{Tzotzil Shepherdesses of Highland Chiapas}

Among the Tzotzil people of highland Chiapas, sheep are an integral element of a mixed-farming system characterized by "extensive pasturing of grasslands with various histories of use" and the "interdependence of sheep raising with production of basic grains." ${ }^{17}$ Sheep production has three major functions here: ecological (provision of soil nutrients via manure), economic (income via sales of animals and handicrafts), and socio-cultural (wool for traditional Tzotzil clothing). Although the first two outputs are fairly common in many regions of Mexico, traditional wool clothing has gradually disappeared. In the last decade, sheep production has been oriented towards meat rather than wool; wool production occurs at very low rates. ${ }^{9}$ Places where wool production persists are generally inhabited by highland indigenous people who still wear traditional clothing, if only for ceremonial purposes.

Sheep production in the highlands of Chiapas contributes at least $30 \%$ of Tzotzil family income, mostly from the sale of woolen handicrafts made by women. Sheep are considered sacred creatures with a soul and an individual name that cannot be slaughtered or eaten; they are members of the family. It is the "traditional wool culture" that distinguishes the Chiapas situation from the others previously noted. A Chiapas sheep is more valuable over a long

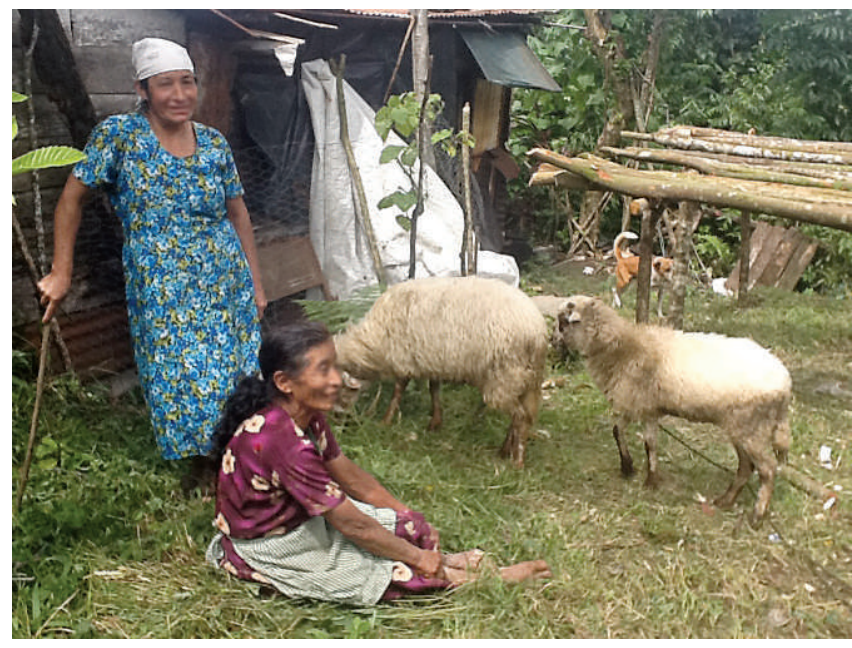

Figure 1. Shepherdesses of highland Chiapas. Photo courtesy of the author.

productive life when compared to just slaughter value, and it appears that this factor gives sheep a higher status in the Chiapas culture when compared to sheep production elsewhere (Fig. 1).

Scholars who work in Chiapas highlight women's responsibility for sheep management, and they use the term "shepherdesses" to describe their role, arguing that sheep production is part of a women's ethnic identity. Women's contribution to the genetic conservation of the Chiapas sheep is also acknowledged. Using this framework as a starting point, participatory research has recently been conducted with women in order to genetically improve Chiapas sheep via selection based on fleece quality, ${ }^{18}$ and to improve animal health to reduce a high neonatal mortality rate. ${ }^{19}$ This is a good example of how explicit recognition of women's roles in sheep production, and involvement of women in sheep research, can bring about improvements in sheep flocks.

\section{How to Move Forward: Gender Tools for Future Research}

My literature review reveals a lack of clarity in terminology and focus with respect to gender and sheep production. The scholarship on Chiapas shepherdesses is the only clear documentation of women's roles in Mexican sheep production. In other words, seemingly only the Tzotzil women of Chiapasout of some 50 ethnic groups in the country-make a notable or well-defined contribution to the household economy via small-scale livestock husbandry.

This cannot be true. Mexican rural women have tended poultry, sheep, and goats since colonial times. More women must be handling small-scale livestock production in today's Mexico. Scholars therefore need to ask new research questions to make women more visible and better understand the roles they play and barriers they face in improving sheep production. Where are the women? What are they doing? What roles do they play in the various mixed-farming systems of 
each region? How do women relate to livestock production? In this section, I offer three conceptual tools or perspectives that may help answer these questions.

1) Research must use the household as the unit of analysis, but without treating the household as an internally homogenous unit. The household embodies inequalities where men and women of different status, kinship ties, gender, and ages have dissimilar workloads and access to resources. Women and men generate income through separate spheres and use it in different ways. Sen ${ }^{20}$ suggests that we use the term "cooperative conflict" in order to fully grasp household decision-making regarding work distribution, animal ownership, adoption of new technologies, and marketing strategies in animal production.

2) The gendered division of labor and management must be central to the analysis. This is not from a descriptive point of view ("who does what"), but rather as a means to assign value to certain activities and power to the people who conduct them. Domestic work, universally assigned to women, comprises a large set of never-ending activities which are not socially valued in spite of their contribution to human welfare. In Latin America, the gendered division of labor defines farm activities as a male occupation. Women are seen as "housewives" regardless of their contribution to agriculture and livestock management. This view must be overcome to distinguish among gendered productive activities. ${ }^{21}$

3) Scholars must analyze how institutions operating at different levels or scales of resolution (i.e., country, region, state, community, family) shape the entitlements that both women and men have over resources that are critical for livestock husbandry (i.e., grazing land, water, crops, fodder). Again, it is not a matter of just describing or stating the obvious (like "women have less access to land than men"), but rather investigating how institutional dynamics create entitlements where "certain social actors may not be able to mobilize some endowments (e.g., capital, labor) that are necessary in order to make effective use of others (e.g., land)." 22 For example, state regulations requiring farmers to support credit applications with land titles make it extremely difficult for women to access such credits because women may not be named on land titles. These regulations actually increase men's abilities to mobilize capital and labor for livestock production, as opposed to women's abilities. The understanding of such dynamics helps clarify who ultimately gets "effective command" over certain resources, for example-livestock. Women may perform many sheep-related activities, but they may not be able to trade animals because credit is only awarded to men. Radel and Coppock (this issue) also underscore the need to answer "how and why" questions that pertain to the creation and maintenance of gender gaps on rangelands around the world.

\section{Synthesis}

Although the size of Mexico's national sheep inventory has increased of late, domestic production still only satisfies a portion of the national demand for mutton, lamb, and wool. Sheep industry advocates call for investments to expand sheep production. Research attention to the socio-cultural context, including gender concerns, is vital for the design of successful strategies leading to the sustainable and equitable growth of Mexico's sheep industry.

In this paper, I have provided examples from the Mexican literature concerning sheep production and women's roles in mixed-farming systems. Women are rarely central in this scholarship. The most common terms used to describe the people who carry out sheep-related activities are: "producers" (no gender provided), "family labor," and "women, children, and the elderly." When the term "producers" is used, and no identifier as to gender is provided, there is no way of knowing who owns the sheep, takes care of the sheep, or makes decisions. In such cases, research or extension programs can focus on the wrong individuals. The terms "family labor" and "women, children, and the elderly" are not very useful either, since they obscure the gender power relations that determine access to and control over resources (i.e., capital, animals, grazing land, water, fodder) - relations that can be critical to production outcomes. Research does not further scrutinize decision-making processes within the household, the gendered division of labor, and entitlement issues over resources. Only the work conducted with the Tzotzil people of the highland Chiapas acknowledges women's roles in sheep production by describing their management practices, traditional knowledge, and contribution to the household economy.

Why is the scholarship on Chiapas different? I can only speculate and offer two tentative answers. The first lies on the use and status given to the sheep. In highland Chiapas, sheep contribute to Tzotzil material and spiritual wellbeing in diverse ways. Women are the major caretakers of such important creatures; thus the women cannot be ignored. In other states - for example Hidalgo - traditional clothing has disappeared, the market for wool handicrafts has declined, and sheep are valued mostly for their meat or as a form of savings. Agriculture has become more market-oriented, land prices have increased, and traditional feeding practices have decreased. ${ }^{23}$ This has all contributed to making sheep more "anonymous" in the production system, and has also made their women caretakers more invisible. If mentioned at all, women are usually clustered under the category of "family labor," a kind of labor that is expected to disappear as sheep producers (read men) adopt more intensive production models.

My second, tentative answer has to do with the approaches used to study sheep production. Scholars in Chiapas use the term agrosilvopastoril when describing the mixed-farming system of the Chiapas highlands. The term involves several components besides livestock and forces investigators to become systems thinkers. Scholars analyze not only the ways in 
which animal husbandry relates to other activities, but also how the process of animal production can be transformedin this case, with wool production. In the Chiapas highlands this analysis inevitably leads, again, to women's important roles in artisan and cloth manufacturing. However, this approach still falls short in examining the gendered division of labor (e.g., men's and women's activities in both livestock and agriculture) as well as gendered differences in access to resources, benefits, and decision-making. More research is needed in order to make such issues tangible to scientists and policy makers.

The third part of my paper offered three gender tools or perspectives that may be useful to explore gender differences. These tools help acknowledge a simple fact: households are made up of people with power and workload differentials. Understanding gender roles and environmental entitlements is essential to capture how these differences actually work. Adopting these tools would help better situate women's roles in sheep production, thus improving their visibility in the livestock scholarship of Mexico.

\section{Does Understanding Women's Roles Matter?}

Mexico needs to increase domestic output of sheep products to better satisfy demand. This requires that scientists and policy makers better understand the diversity of mixedfarming systems in terms of the constraints that limit improvements in productivity. It is likely that rural women are a major source of knowledge in this regard. Rather than merely generating new technologies to improve animal nutrition, breeding, and health, scientists, extension agents, and policy makers must put women's contribution to sheep production at the forefront. In many instances, it will be women who make the day-to-day management decisions. With a clearer understanding of the roles of women, outreach programs can be designed that more effectively deliver new technologies and management practices. Policies can be developed that are more gender-neutral and hence have positive effects on women as well as men. This can speed up the rate of innovation adoption or technology transfer, which can be notoriously low. ${ }^{24}$

Women's labor, knowledge, and management strategies must be incorporated into research and policy design. Their disadvantages in terms of lack of control over critical resources essential for livestock production can be overcome through technical and policy interventions. By identifying some of the issues, and offering some conceptual tools to deal with them, this paper has taken an initial step in this direction. Hopefully, others will follow this lead.

\section{Acknowledgments}

The International Affairs Committee and the Board of Directors of the Society for Range Management (SRM) are thanked for providing travel support for the author to present a talk at the "Women as Change Agents in the World's Rangelands" symposium in Oklahoma City that served as the basis for this article. Two anonymous referees are appreciated for their comments on an earlier version of this paper. Also, special thanks are due to Layne Coppock for his valuable input and hard work in organizing the symposium and putting together this special issue of Rangelands.

\section{References}

1. Parsons, D., C. F. Nicholson, R. W. Blake, Q. M. Ketterings, L. Ramírez-Aviles, J. H. Cherney, and D. G. Fox. 2011. Application of a simulation model for assessing integration of smallholder shifting cultivation and sheep production in Yucatán, Mexico. Agricultural Systems 104:13-19.

2. World Bank. 2009. Gender in agriculture source book. Washington, DC, USA: The World Bank. 764 p.

3. FAO. 2012. Invisible guardians. Women manage livestock diversity. Rome, Italy: FAO. 174. 56 p.

4. Nahed-Toral, J. 2002. Animales domésticos y agroecosistemas campesinos. (In Spanish.) Revista LEISA junio:10-11.

5. Mexican Association of Sheep Breeders. 2007. Sheep inventory. Mexico City, Mexico: AMCO. 32 p.

6. SAGARPA. 2011. Servicio de Información agroalimentaria y pesquera. Available at: http://www.campomexicano.gob. $\mathrm{mx} /$ portal_siap/Integracion/EstadisticaBasica/Pecuario/ PoblacionGanadera/ProductoEspecie/ovino.pdf. Accessed 20 January 2013.

7. Morales, M., J. P. Martínez-Dávila, G. Torres-HernánDez, and J. E. Pacheco-Velasco. 2004. Evaluación del potencial para la producción ovina con el enfoque de agroecosistemas en un ejido de Veracruz, México. (In Spanish). Técnicas Pecuarias de México 42(3):347-359.

8. Salinas-González, H., F. Echavarría-Chaires, M. J. Flores-Nájera, M. A. Flores-Ortiz, R. Gutiérrez-Luna, And A. F. Rumayor-Rodriguez. N/D. Tecnología en sistemas de producción caprinos en el semi-desierto de Zacatecas. Available at: http://biblioteca.inifap.gob.mx:8080/xmlui/bitstream/handle/ 123456789/1939/Tecnologia\%20en\%20sistemas\%20de\%20 produccion\%20caprinos\%20en\%20el\%20simidesierto\%20de\%20 zacatecas.pdf?sequence=1. Accessed 1 August 2013.

9. Financiera Rural. 2010. Monografía lana. Mexico City, Mexico: Financiera Rural. 7 p.

10. Arteaga-Castelán, J. D. 2012. La ovinocultura en México. Realidad, retos y oportunidades. Proceedings of the Second Forum on Sheep; 18-19 October 2012; Veracruz, Ver., Mexico. Veracruz, Ver., Mexico: Unión Nacional de Ovinocultores. p. $1-53$.

11. Vieyra, J., J. P. Muñoz, E. Manrique, and J. C. R. Santos. 2009. Assessment of sheep farming systems within San Salvador District (State of Hidalgo). Options Méditerranéennes 91:249-252.

12. Pérez-Hernández, P., A. Arrieta-González, B. Candelaria-Martínez, O. Arroniz-Sánchez, S. López-Ortiz, H. Chalate-Molina, P. Díaz-Rivera, and C. Ahuja-Aguirre. N/D. Caracterización del sistema producto ovino en el estado de Veracruz. Veracruz, Ver., Mexico: Colegio de Postgraduados and Fundación PRODUCE Veracruz. 53 p. 
13. Martínez-González, E. G., M. Muñoz-Rodríguez, J. G. García-Muñiz, V. H. Santoyo-Cortés, J. R. AltamiranoCárdenas, and C. Romero-Márquez. 2011. El fomento de la ovinocultura familiar en México mediante subsidios en activos: lecciones aprendidas. (In Spanish). Agronomia Mesoamericana 22(2):367-377.

14. Arriaga-Jordán, C. M., A. M. Pedraza-Fuentes, E. G. Nava-Bernal, M. C. Chávez-Mejía, and O. A. CastelánOrtega. 2005. Livestock agrodiversity of Mazahua smallholder campesino systems in the highlands of central Mexico. Human Ecology 33(6):821-845.

15. Deere, C. D. 1995. What difference does gender make? Rethinking peasant studies. Feminist Economics 1(1):53-72.

16. Arriaga-Jordán, C. M. and R. A. Pearson. 2004. The contribution of livestock to smallholder livelihoods: the situation in Mexico. In: E. Owen, T. Smith, M.A. Steele, S. Anderson, A.J. Duncan, and M. Herrero [EDs.]. Responding to the livestock revolution: the role of globalization and implications for poverty alleviation. Nottingham, UK: Nottingham University. p. 99-115.

17. Gómez-Castro, H., J. Nahed-Toral, Q. López-Tirado, T. Alemán-Santillán, M. Parra-Vázquez, S. CortinaVillar, R. Pinto-Ruiz, and F. Guevara-Hernández. 2011. Holistic conceptualization of the sheep production system of the Chiapas highlands. Research Journal of Biological Sciences 6(7):314-321.

18. Perezgrovas-Garza, R., and H. Castro-Gámez. 2000. El borrego Chiapas y el sistema tradicional de manejo de ovinos entre las pastoras tzotziles. (In Spanish). Archivos de Zootecnia 49:391-403.
19. Alemán-Santillán, T., J. L. Méndez, Á. MartínezVÁzquez, And L. Hernández-López. 2002. Retos de un sistema productivo indígena: altos de Chiapas. (In Spanish). Revista LEISA junio:12-13.

20. Sen, A. 1987. Gender and cooperative conflicts. Helsinki, Finland: World Institute for Development Economics Research, United Nations University, Working Paper 18. 58 p.

21. Deere, C. D., and M. León de Leal. 2003. The gender asset gap: land in Latin America. World Development 31(6): 925-047.

22. Leach, M. R. Mearns and I. Scoones. 1999. Environmental entitlements: dynamics and institutions in community-based natural resource management. World Development 17(2):225247.

23. VÁzquez-García, V., And C. Muñoz-Rodriguez. 2012. Diagnóstico sobre medio ambiente y desarrollo sustentable con perspectiva de género en el estado de Hidalgo. Mexico City, Mexico: Instituto Hidalguense de las Mujeres. 75 p.

24. Rogers, E. M. 2003. Diffusion of innovations. New York, NY, USA: Free Press. 551 p.

Author is Professor, Dept of Rural Development, Colegio de Postgraduados, Montecillo, Texcoco, México,verovazgar@yahoo.com. $m x$.

Rangelands 35(6):41-46

doi: 10.2111/RANGELANDS-D-13-00029.1

(C) 2013 The Society for Range Management 